\title{
Preface
}

\author{
Jørgen Cohn University of Tromsø, Guest Editor
}

It is well known that torture of human beings has been carried out during thousands of years and at the present time exists in most parts of the world, conducted by different ideologies or regimes in different geographical areas and affecting people of different ethnic origins.

The involvement of health care professionals in the scientific and practical performance of this cruel and un-ethical process has, however, not been highlighted. The main topic of this publication is the involvement of professional medical doctors in the course of torture in, generally speaking, the following ways:

1. Medical scientific knowledge and experience is used in the design of the methods and techniques of torture, for example pharmacological torture.

2. Doctors teach the torturers/perpetrators regarding the practical application of these methods.

3. Doctors actively participate in carrying out torture and in executions in relation to the death penalty.

4. Doctors are present - 'passive' - during the implementation of torture (in more than sixty per cent of cases) for example monitoring the clinical condition of the victim in order to prevent death; are present when the death sentence is carried out, and then write out death certificates. Many of these are later shown by forensic documentation to be false.

Against these negative aspects of the medical profession, we have to set some positive medical initiatives:

1. Several doctors are working at hospitals and other medical centres dealing with refugees and torture victims in order to diagnose the different consequences and sequelae of torture, to treat and rehabilitate the survivors or to arrange medico-legal autopsies, ie forensic medical documentation of torture.

These doctors are also involved in informing and teaching health care professionals about diagnostic procedures and the rehabilitation of torture victims.

2. More doctors are engaging in the protection and support of colleagues who are trying to help people who have been subjected to torture and who are therefore themselves threatened and in real danger of personal reprisals, for example persecution or liquidation, because of their respect for the principles of human rights.

3. Doctors are becoming more committed to intervening in this area, for instance by making accusations against and placing restrictions upon colleagues who participate in torture. These interventions include exclusion from medical work, from scientific research and from membership of medical societies or organisations.

This supplement is based on an international symposium, Torture and the Medical Profession, which was held at the University of Troms $\emptyset$ in June $\rightleftharpoons$ 1990.

\section{Contributors and topics}

Professor Eitinger presents a review of the historical perspective of torture; he is followed by Dr Pross who writes about the Nazi doctors in Germany. The present prevalence of torture is discussed by Dr Kemp Genefke and reviews on the involvement of medical doctors in torture are given by Drs Lavik, Rasmussen and Vesti.

Doctors' various activities in torture are illustrated by Dr Bojar (Czechoslovakia), Dr Cilasun (Turkey), Dr Dowdall (South Africa), Dr Kordon (Argentina), Dr Pagaduan-Lopez (The Philippines), Dr Martirena (Uruguay), Dr Mehdi (Pakistan), Dr Seelmann (Chile), Dr Ternak (Hungary) and Dr Umiastowski (Poland).

Dr Gluzman presents a review of the abuse of psychiatry in the Soviet Union. This is followed by an article by Dr Lansen, on psychiatric experience with victims and perpetrators and the counter-transference feelings generated in the therapist.

Professors Beshir, Espersen and Sørensen discuss the legal aspects and the conventions against torture. In addition, the late Dr Dawson describes the British Medical Association's view of doctors and torture and Dr Jaffe, from the French Association for Victims of Repression in Exile, writes of her association's experiences. 